\title{
Proces wytłaczania jednoślimakowego z zastosowaniem dozownika - zwiększanie skali
}

\author{
Andrzej Nastaj ${ }^{1), *)}$ (ORCID ID: 0000-0002-5040-6733) \\ DOI: dx.doi.org/10.14314/polimery.2021.9.4
}

\begin{abstract}
Streszczenie: Opracowano metodę zwiększania skali procesu wytłaczania jednoślimakowego z dozowaniem tworzywa przy użyciu dozownika. Badania przeprowadzono na podstawie modelu komputerowego procesu przy zastosowaniu algorytmów genetycznych (technik ewolucyjnych). Podstawę metody stanowi program symulacji procesu wytłaczania GSEM (Global Screw Extrusion Model), który jest źródłem danych do optymalizacji, oraz specjalnie opracowany program zwiększania skali procesu GASES ST (Genetic Algorithm Screw Extrusion Scaling for Starve). Prace dotyczyły zmiany skali z poziomu wytłaczarki o średnicy ślimaka $D=45 \mathrm{~mm}$ do poziomu wytłaczarki o $D=60 \mathrm{~mm}$, przy zachowaniu takiego samego stosunku $L / D$. Na podstawie symulacji zoptymalizowano szybkość obrotową ślimaka wytłaczarki, temperaturę poszczególnych stref układu uplastyczniającego i szybkość dozowania. Proces przeprowadzono wg kryterium minimalnego jednostkowego zużycia energii, maksymalnej szybkości uplastyczniania i najniższej temperatury tworzywa na wyjściu z głowicy.
\end{abstract}

Słowa kluczowe: wytłaczanie jednoślimakowe, zwiększanie skali, modelowanie.

\section{Scaling up of starve fed single screw extrusion}

Abstract: A method of scaling up the starve fed single screw extrusion of polymers has been developed. The research was carried out on the basis of a computer model of the process with the use of genetic algorithms (evolutionary techniques). The basis of the method is the GSEM (Global Screw Extrusion Model) extrusion simulation program, which is the source of data for optimization, and the specially developed GASES ST (Genetic Algorithm Screw Extrusion Scaling for Starve) program. The work involved changing the scale from the extruder with the screw diameter $D=45 \mathrm{~mm}$ to the extruder with $D=60 \mathrm{~mm}$, while maintaining the same $L / D$ ratio. Based on the simulation, the rotational screw speed, the temperature of individual zones of the plasticizing unit and the feeding rate were optimized. Scaling up was carried out according to the criteria of energy unit consumption, polymer melting rate and die temperature.

Keywords: single screw extrusion, scaling-up, modeling.

Systemy CAD/CAE (komputerowe wspomaganie projektowania/komputerowe wspomaganie prac inżynierskich) stanowią użyteczne narzędzie do projektowania procesów przetwórczych i przewidywania ich przebiegu na podstawie danych wejściowych (materiałowych, technologicznych i geometrycznych). Nie umożliwiają one jednak optymalizacji warunków przetwórstwa i zwiększania skali tych procesów wg określonych kryteriów, np. maksymalizacji wydajności procesu lub minimalizacji zużycia energii.

Optymalizacja procesu wytłaczania polega na tworzeniu wielowymiarowej przestrzeni danych wyjściowych na podstawie danych wejściowych i poszukiwaniu w tej przestrzeni wartości ekstremalnych. Natomiast zmiana skali procesu odbywa się przy zachowaniu parametrów

1) Politechnika Warszawska, Instytut Technik Wytwarzania, ul. Narbutta 85, 02-524 Warszawa.

*) Autor do korespondencji: andrzej.nastaj@pw.edu.pl procesu na poziomie maksymalnie zbliżonym do parametrów procesu odniesienia. Dane do optymalizacji i zwiększenia skali mogą pochodzić z badań doświadczalnych lub symulacyjnych, przy czym bardziej efektywne są działanie na podstawie danych symulacyjnych. Optymalizacja i zwiększenie skali procesu wytłaczania są zagadnieniami złożonymi ze względu na bardzo dużą liczbę potencjalnych kryteriów, a także bardzo dużą liczbę parametrów procesowych, materiałowych, geometrycznych i technologicznych.

Znane są metody badania i opisu procesów fizycznych z zastosowaniem technik sztucznej inteligencji, np. sieci neuronowych, algorytmów genetycznych, czy systemów rozmytych. Szczególne znaczenie w przypadku wytłaczania mają metody algorytmów genetycznych. Zastosowano je do optymalizacji procesu wytłaczania jednoślimakowego z dozowaniem grawitacyjnym [1-7], dwuślimakowego współbieżnego [8-14] i jednoślimakowego z dozowaniem za pomocą dozowników masowych 
lub objętościowych [15-17]. Brak jest jednak informacji dotyczących zwiększania skali procesu wytłaczania dwuślimakowego i jednoślimakowego z zastosowaniem dozowników, pomimo opracowania modeli matematycznych tych procesów [18-24].

Proces wytłaczania może być prowadzony bez użycia dozownika tj. $\mathrm{w}$ warunkach dozowania grawitacyjnego (ang. flood fed extrusion) lub z użyciem dozownika (ang. starve fed extrusion). Wytłaczanie jednoślimakowe jest zwykle realizowane bez użycia dozownika, natomiast wytłaczanie dwuślimakowe z zastosowaniem dozownika objętościowego lub masowego. W przypadku wytłaczania $\mathrm{w}$ warunkach dozowania grawitacyjnego strefa zasilania układu uplastyczniającego jest całkowicie wypełniona tworzywem. Uplastycznianie i mieszanie tworzywa zachodzi stosunkowo wolno, a wydajność procesu zależy głównie od prędkości obrotowej ślimaka. Natomiast w procesie wytłaczania z użyciem dozownika ślimak w strefie zasilania jest tylko częściowo wypełniony tworzywem, co nie generuje ciśnienia, a uplastycznianie i mieszanie tworzywa zachodzi znacznie szybciej. W tym przypadku kluczowym parametrem określającym wydajność procesu jest szybkość dozowania.

Schemat wytłaczania jednoślimakowego bez i z dozownikiem przedstawiono na rys. 1 oraz 2 . W przypadku wytłaczania $\mathrm{z}$ dozowaniem grawitacyjnym uplastycznianie zachodzi zgodnie ze znanym modelem Tadmora. Natomiast $\mathrm{w}$ procesie wytłaczania $\mathrm{z}$ użyciem dozownika uplastycznianie zachodzi wg mechanizmu dwuetapowego tj. wskutek przewodzenia ciepła w strefie częściowo wypełnionego ślimaka i rozpraszania energii w strefie całkowicie wypełnionego ślimaka (uplastycznianie dyspersyjne) [22, 23]

Niewiele jest doniesień literaturowych dotyczących wytłaczania jednoślimakowego z użyciem dozownika $[25,26]$. Wilczyński i współpr. jako pierwsi opracowali

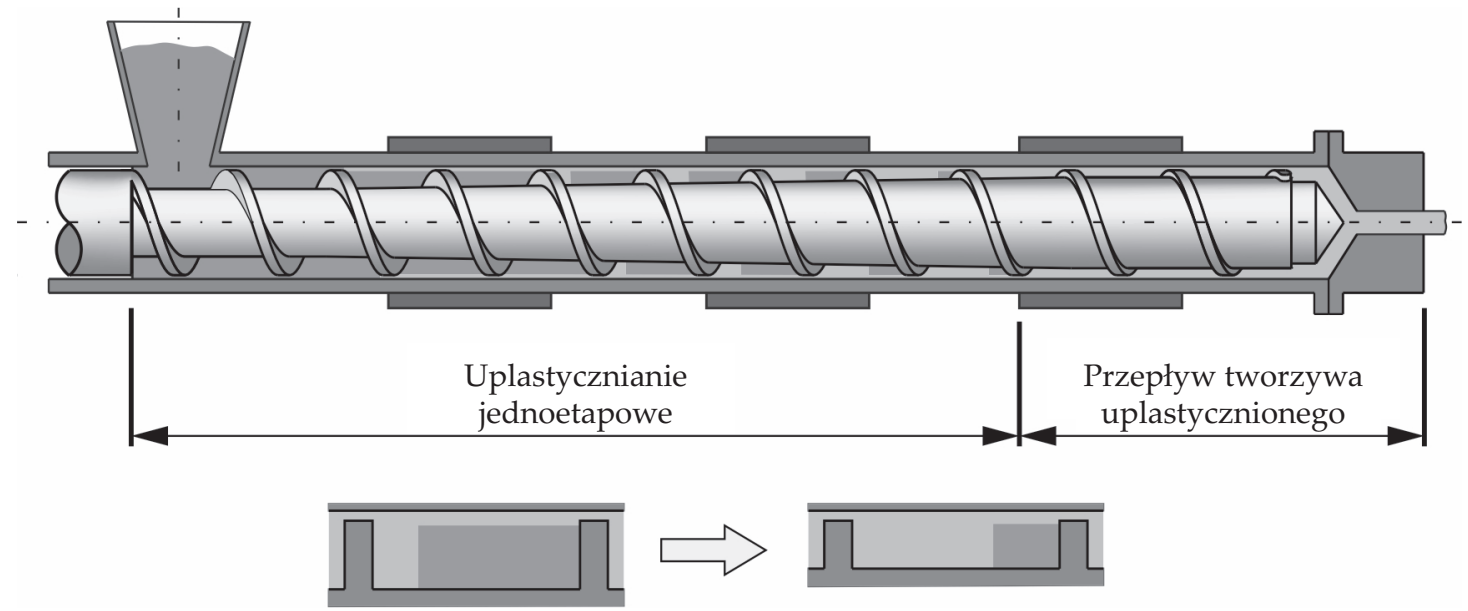

Rys. 1. Schemat klasycznego wytłaczania (uplastycznianie wg mechanizmu Tadmora)

Fig. 1. Schematic of flood fed extrusion (Tadmor melting mechanism)
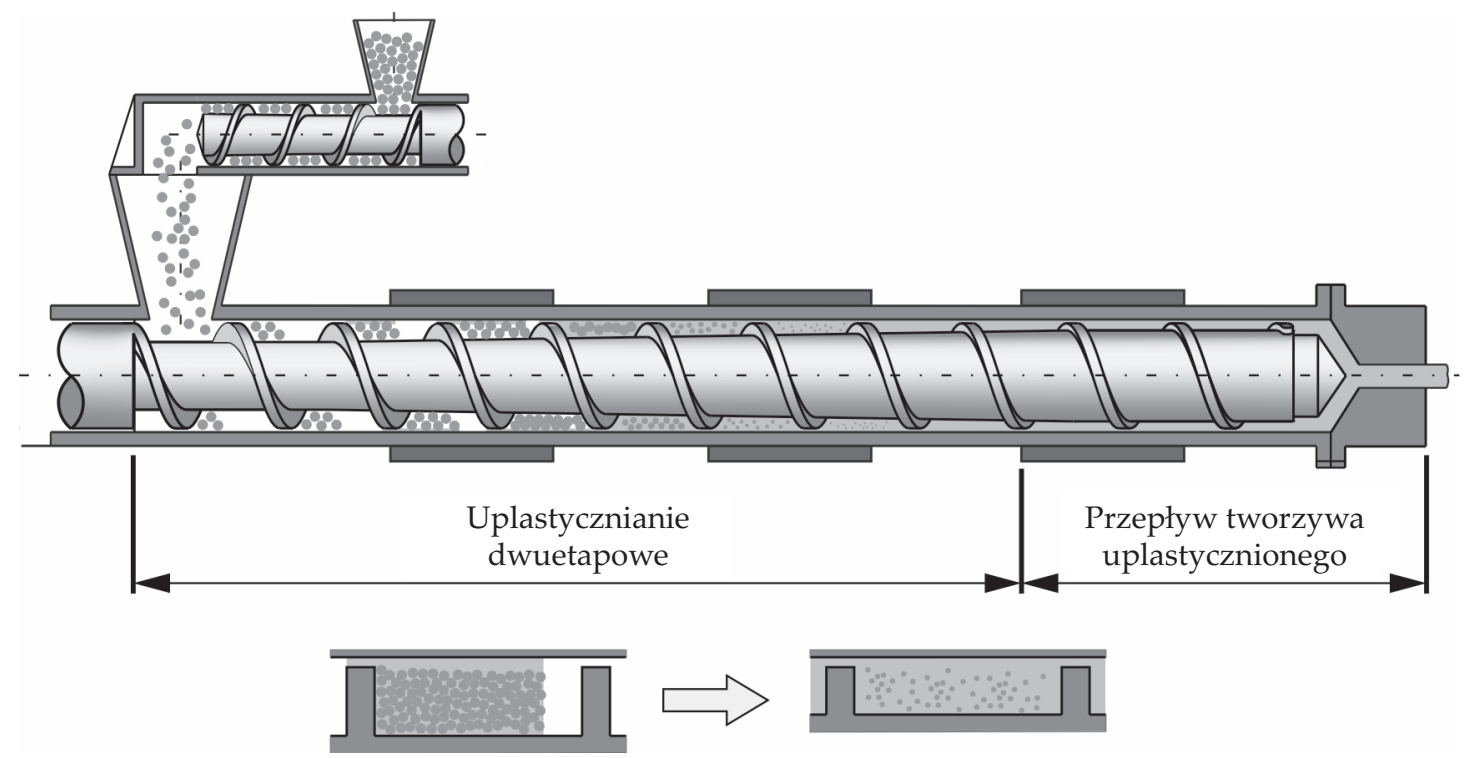

Rys. 2. Schemat wytłaczania z dozowaniem (uplastycznianie dwuetapowe)

Fig. 2. Schematic of starve fed extrusion (two-stage melting mechanism) 
model wytłaczania jednoślimakowego z dozowaniem [22-24]. Następnie rozwinęli ten model o wytłaczanie z zastosowaniem ślimaków o specjalnej konstrukcji $[27,28]$ oraz wytłaczanie mieszanin polimerowych $[29,30]$ i kompozytów polimerowo-drzewnych (ang. Wood Polymer Composites) [31, 32].

\section{PROGRAM DO ZWIĘKSZANIA SKALI PROCESU WYTŁACZANIA}

Podstawą koncepcji zwiększania skali jest teoria podobieństwa, która definiuje zależności pomiędzy parametrami fizycznymi mającymi wpływ na dane zjawisko, np. przepływ tworzywa w układzie uplastyczniającym. Spełnienie tych zależności zapewnia zachowanie podobieństwa między układami o różnej wielkości. Przykładowo, liczba Reynoldsa Re określa stosunek sił bezwładności do sił lepkości i jest kryterium stateczności ruchu płynów. Definiuje czy ruch płynu jest laminarny czy turbulentny. Natomiast mająca kluczowe znaczenie w przetwórstwie tworzyw liczba Brinkmana Br określa stosunek ciepła wytwarzanego wskutek rozpraszania energii do ciepła przekazywanego w wyniku przewodzenia.

Pierwsze prace dotyczące zwiększania skali prowadzono na podstawie jednoparametrowych kryteriów procesu. Zastosowanie modelowania komputerowego umożliwiło zmianę skali wytłaczania na podstawie charakterystyki całego procesu. Zagadnienia te były szeroko omawiane w wielu publikacjach [33-39]. Zwiększanie skali procesu wytłaczania jednoślimakowego na podstawie algorytmów genetycznych polega na pozyskiwaniu danych z symulacji procesu. Podstawę badań symulacyjnych stanowi program GSEM (ang. Global Screw Extrusion Model) [40], który jest rozwiniętą wersją programu SSEM (ang. Single Screw Extrusion Model) [41] umożliwiającą symulację procesu wytłaczania jednoślimakowego z zastosowaniem dozownika. Ogólne podstawy modelowania różnych procesów wytłaczania (bez lub z użyciem dozownika) przedstawiono $\mathrm{w}$ pracy [42].

Wzorowane na naturalnej ewolucji algorytmy genetyczne są stosowane do wyszukiwania optymalnych rozwiązań. Parametry zwiększania skali procesu są zakodowane $\mathrm{w}$ postaci uporządkowanych ciągów znaków, tzw. chromosomów. Zespół chromosomów stanowi genotyp, który reprezentuje parametry procesu, np. prędkość obrotową ślimaka czy parametry geometryczne.

Procedura algorytmu polega na losowaniu populacji początkowej parametrów zadania i ich ocenie na podstawie wartości funkcji celu, np. różnicy między względną długością strefy uplastyczniania w procesie odniesienia i procesie projektowanym. Parametry generujące najmniejsze wartości funkcji celu uczestniczą w reprodukcji. Genotypy tych parametrów podlegają krzyżowaniu (wymianie elementów chromosomów) i mutacji (wprowadzaniu losowych zmian genotypu). W rezultacie tworzy się drugie pokolenie, poddawane ocenie i pro- cedura jest powtarzana do momentu uzyskania poszukiwanego rozwiązania.

W ujęciu ogólnym zwiększanie skali na podstawie algorytmów genetycznych obejmuje następujące etapy [43]:

- zdefiniowanie globalnej funkcji celu (kryterium zwiększania skali),

- zdefiniowanie algorytmu genetycznego (ustalenie sposobu kodowania parametrów wejściowych, określenie długości ciągu znaków kodujących poszczególne parametry, ustalenie wielkości „populacji” wejściowej, przyjęcie metody selekcji chromosomów, określenie prawdopodobieństwa występowania operatorów krzyżowania i mutacji, przyjęcie kryterium zatrzymania ewolucji),

- zastosowanie algorytmu genetycznego (losowy wybór populacji początkowej, ocenę przystosowania chromosomów w populacji wg wartości funkcji celu, sprawdzenie warunku zatrzymania ewolucji, wybór chromosomów do następnej populacji, wykonanie operacji krzyżowania i mutacji, generację nowej populacji, wybór rozwiązania optymalnego).

Zwiększanie skali $\mathrm{w}$ odniesieniu do określonego typu procesu wytłaczania, np. jednoślimakowego bez lub z użyciem dozownika, wymaga jednak opracowania indywidualnych procedur, które nie mają charakteru uniwersalnego i działają jedynie $\mathrm{w}$ obrębie danego sposobu wytłaczania. Dlatego opracowane dla klasycznego wytłaczania procedury zwiększania skali nie mają zastosowania do wytłaczania z użyciem dozownika, co wynika z odmienności tych procesów, a w konsekwencji ich modeli komputerowych.

$\mathrm{W}$ procesie wytłaczania z dozowaniem grawitacyjnym natężenie przepływu tworzywa nie jest ustalone lecz wynika z tzw. punktu pracy wytłaczarki, który określa wydajność wytłaczania i ciśnienie wytłaczanego tworzywa. Podstawę algorytmu obliczeń stanowi wyznaczenie natężenia przepływu oraz rozkładu ciśnienia tworzywa w układzie uplastyczniającym wytłaczarki i w głowicy. Obliczenia z zastosowaniem procedur iteracyjnych są realizowane $\mathrm{w}$ kierunku od leja zasypowego do głowicy, czyli „do przodu”. Natomiast w procesie wytłaczania z zastosowaniem dozownika wydajność procesu jest ustalona i znana. Ponieważ w tym przypadku strefa zasilania układu uplastyczniającego wytłaczarki jest tylko częściowo wypełniona tworzywem i nie jest $w$ niej generowane ciśnienie (nie są znane warunki przepływu), kluczowe jest zastosowanie iteracyjnej procedury, która umożliwi wyznaczenie miejsca w którym ślimak jest całkowicie wypełniony. Obliczenia przebiegają w kierunku przeciwnym niż w przypadku wytłaczania $\mathrm{z}$ dozowaniem grawitacyjnym tj. od głowicy do leja zasypowego, czyli „do tyłu”. Koncepcję modelowania obu procesów przedstawiono schematycznie na rys. 3.

Program GASES ST (ang. Genetic Algorithm Screw Extrusion Scaling for Starve) umożliwia zwiększanie skali procesu wytłaczania z użyciem dozownika z dowolną 


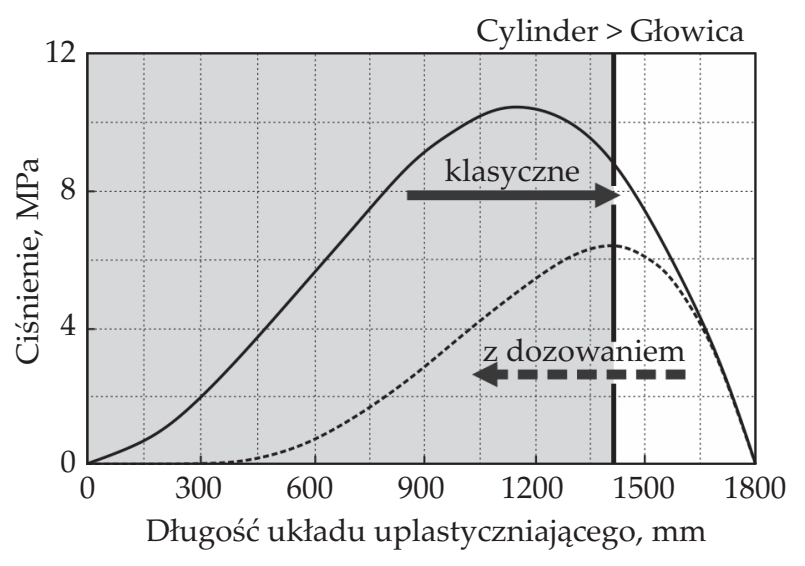

Rys. 3. Schemat ideowy modelowania procesu klasycznego wytłaczania i wytłaczania z użyciem dozownika

Fig. 3. Schematic diagram for modeling of flood fed and starve fed extrusion

liczbą zmiennych, przy różnych, w zasadzie dowolnych kryteriach. Dokładność przeszukiwania powierzchni odpowiedzi jest wyznaczana przez liczbę przyjętych przedziałów zakresu badanych parametrów, która w programie GASES ST wynosi maksymalnie $2^{255}$, co wynika z długości zapisu tych liczb w postaci binarnej. Selekcja jest realizowana za pomoca metody ",koła ruletki” [6, 16]. Warunkiem zatrzymania procedury jest 100-krotne wystąienie optymalnego zestawu danych.

Koncepcję zwiększania skali procesu wytłaczania jednoślimakowego w warunkach dozowania grawitacyjnego autor przedstawił we wcześniejszych publikacjach $[43,44]$. Przedmiotem niniejszego artykułu jest zwiększanie skali procesu wytłaczania jednoślimakowego z użyciem dozownika przy zastosowaniu algorytmów genetycznych i specjalnie opracowanego programu GASES ST.

\section{CZĘŚĆ DOŚWIADCZALNA}

Program badań obejmował zwiększanie skali procesu wytłaczania jednoślimakowego z zastosowaniem dozownika z poziomu wytłaczarki odniesienia o średnicy ślimaka $D=45 \mathrm{~mm}$ do poziomu wytłaczarki projektowanej o średnicy ślimaka $D=60 \mathrm{~mm}$ przy zachowaniu stosunku długości ślimaka do średnicy $L / D$ (rys. 4). Badania przeprowadzono $\mathrm{w}$ takich samych warunkach jak dla procesu wytłaczania z dozowaniem grawitacyjnym [43].

Do badań stosowano polietylen dużej gęstości (PE-HD) Rigidex 6070EA (BP Chemicals) o gęstości $0,952 \mathrm{~g} / \mathrm{cm}^{3}$, masowym wskaźniku szybkości płynięcia $M F R=7,6 \mathrm{~g} / 10 \mathrm{~min}\left(190^{\circ} \mathrm{C} ; 2,16 \mathrm{~kg}\right)$ i temperaturze topnienia $135^{\circ} \mathrm{C}$.

Właściwości reologiczne tworzywa opisano na podstawie równania Kleina:

$$
\ln \eta=A_{0}+A_{1} \ln \dot{\gamma}+A_{11} \ln ^{2} \dot{\gamma}+A_{12} T \ln ^{2} \dot{\gamma}+A_{2} T+A_{22} T^{2}
$$

gdzie: $\eta$ - lepkość, $\dot{\gamma}$ - szybkość ścinania, $T$ - temperatura, a $A_{0}, A_{1}, A_{11}, A_{12}, A_{2}$ i $A_{22}$ - parametry równania Kleina $\left(A_{0}=1,092 \cdot 10^{1}, A_{1}=-2,184 \cdot 10^{-1}, A_{11}=-3,686 \cdot 10^{-2}\right.$, $\left.A_{12}=1,026 \cdot 10^{-3}, A_{2}=-2,268 \cdot 10^{-2}, A_{22}=2,115 \cdot 10^{-5}\right)$.

Zwiększanie skali zrealizowano $\mathrm{w}$ odniesieniu do procesu wytłaczania, którego warunki technologiczne ustalono w wyniku optymalizacji. Optymalizacja procesu odniesienia została przeprowadzona wg kryterium maksymalnej wydajności $Q_{S T \text { max' }}$ minimalnego jednostkowego zużycia energii $E_{\text {iST min }}$ i minimalnej temperatury tworzywa na wyjściu z głowicy $T_{\text {ST tw min }}$.

Globalną funkcję celu zdefiniowano jako:

$$
F_{S T \text { io }}=\sqrt[3]{Q_{S T i_{-} z n o r m} \cdot E_{j S T i_{-} z n o r m} \cdot T_{\text {tw ST i_znorm }}}
$$

w której:

$$
\begin{aligned}
& Q_{S T i_{-} \text {znorm }}=\frac{Q_{S T i}-Q_{S T \text { min }}}{Q_{S T \text { max }}-Q_{S T \text { min }}} \\
& E_{j S T \text { I_znorm }}=\frac{E_{j S T i}-E_{j S T \text { min }}}{E_{j S T \text { max }}-E_{j S T \text { min }}} \\
& T_{t w S T i_{-} z n o r m}=\frac{T_{t w S T i}-T_{t w S T \text { min }}}{T_{t w S T \text { max }}-T_{\text {twST min }}}
\end{aligned}
$$

gdzie: $F_{S T \text { i }}-$ globalna funkcja celu procedury optymalizacji, $Q_{S T \text { i_znorm }}$ - znormalizowana wartość masowego natężenie przepływu tworzywa, $E_{j S T i_{-} z n o r m}-$ znor-
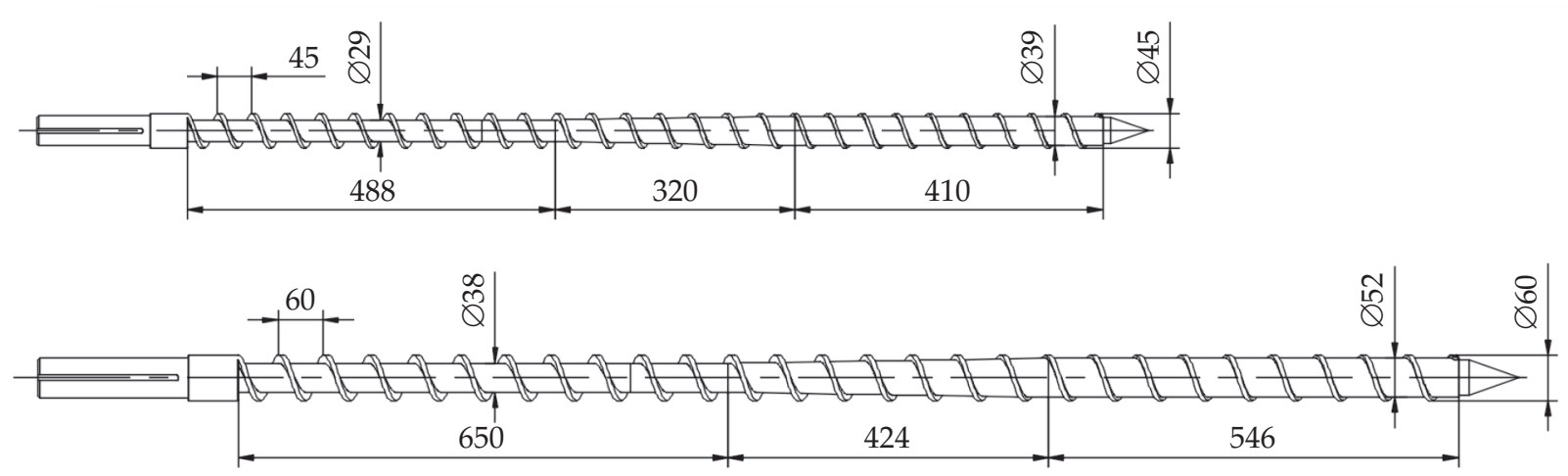

Rys. 4. Geometria ślimaka: a) wytłaczarka odniesienia, b) wytłaczarka projektowana [43]

Fig. 4. Extruder screw geometry: a) reference extruder, b) target extruder 
malizowana wartość jednostkowego zużycia energii, $T_{\text {tw ST i_znorm }}$ - znormalizowana wartość temperatury tworzywa na wyjściu z głowicy, $i$ - numer kolejnej wartości ze zbioru danych.

Optymalizację procesu odniesienia przeprowadzono w zakresie prędkości obrotowej ślimaka $\mathrm{N}=20-80$ obr./min, temperatury $\mathrm{w}$ kolejnych strefach układu uplastyczniającego wytłaczarki: $T_{\mathrm{I}}=150^{\circ} \mathrm{C}$, $T_{\text {II }}=150-240^{\circ} \mathrm{C}, \quad T_{\text {III }}=150-240^{\circ} \mathrm{C}, T_{\text {IV }}=150-240^{\circ} \mathrm{C}$ oraz dozowania tworzywa $Q_{t w s T}=27-32 \mathrm{~kg} / \mathrm{h}$.

Maksymalną wartość funkcji celu uzyskano przy prędkości obrotowej ślimaka $N=80 \mathrm{obr}$ /min i temperaturze układu uplastyczniającego wytłaczarki: $T_{\mathrm{I}}=150^{\circ} \mathrm{C}$, $T_{\text {II }}=234^{\circ} \mathrm{C}, T_{\text {III }}=229^{\circ} \mathrm{C}, T_{\text {IV }}=223^{\circ} \mathrm{C}$ oraz masowym natężeniu przepływu tworzywa $Q_{t w s T}=27 \mathrm{~kg} / \mathrm{h}$. Tym optymalnym warunkom, wg przyjętych kryteriów, odpowiadają następujące wartości parametrów wyjściowych procesu: masowe natężenie przepływu: $Q_{S T}=Q_{t w S T}=27 \mathrm{~kg} / \mathrm{h}$, jednostkowe zużycie energii $E_{j S T}=454 \mathrm{~kJ} / \mathrm{kg}$ i temperatura tworzywa na wyjściu $z$ głowicy: $T_{t w ~}=223^{\circ} \mathrm{C}$. W odniesieniu do zoptymalizowanego procesu zwiększono jego skalę, w analogicznym zakresie danych wejściowych i przy zwiększonym dozowaniu tworzywa $Q_{t w s T}=36-42 \mathrm{~kg} / \mathrm{h}$.

Skalę procesu zwiększono wg następujących kryteriów: jednostkowego zużycia energii $E_{j S T}$, temperatury tworzywa na wyjściu z głowicy $T_{t w s T}$ i względnej „długości uplastyczniania" $L_{\text {uplast } S T}$, która jest definiowana stosunkiem długości ślimaka niezbędnej do uplastycznienia tworzywa do całkowitej długości ślimaka.

Globalna funkcja celu została zdefiniowana w postaci

$$
F_{S T \text { is }}=\left|1-\frac{E_{j S T_{A}}}{E_{j S T_{B} i}}\right|+\left|1-\frac{T_{t w S T_{A}}}{T_{t w S T_{B} i}}\right|+\left|1-\frac{L_{\text {uplast } S T_{A}}}{L_{\text {uplast } S T_{B} i}}\right|
$$

gdzie: $F_{S T \text { is }}$ - globalna funkcja celu zwiększania skali procesu, $E_{i S T A}$-jednostkowe zużycie energii wytłaczarki odniesienia, $E_{\text {jST B } i}$ - jednostkowe zużycie energii wytłaczarki projektowanej, $T_{t w S T A}$ - temperatura tworzywa na wyjściu z głowicy wytłaczarki odniesienia, $T_{\text {tw ST B } i}$-temperatura tworzywa na wyjściu z głowicy wytłaczarki projektowanej, $L_{\text {uplast ST A }}$ - względna „długość uplastyczniania" wytłaczarki odniesienia, $L_{\text {uplast ST B } i}$ - względna „długość uplastyczniania” wytłaczarki projektowanej, $i$ - numer kolejnej wartości ze zbioru danych.

\section{WYNIKI BADAŃ I ICH OMÓWIENIE}

Wyniki badań przedstawiono w postaci ogólnej charakterystyki procesu wytłaczania obejmującej podstawowe jego parametry tj. rozkład ciśnienia i temperatury tworzywa, pobór mocy, przebieg uplastyczniania tworzywa oraz stopień wypełnienia ślimaka.

Ważnymi parametrami procesu wytłaczania są szybkość uplastyczniania tworzywa, wyrażona przez stopień uplastyczniania SBP (ang. solid bed profile), oraz stopień

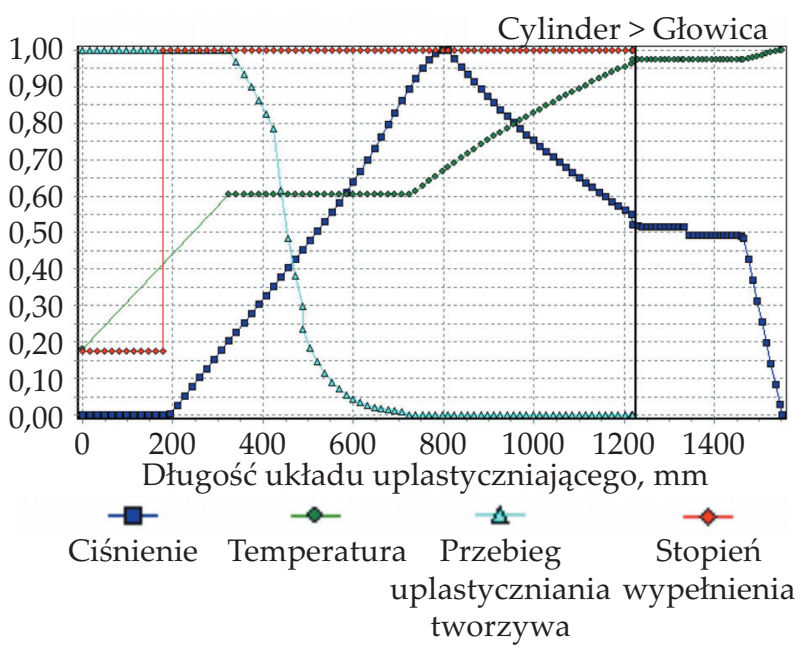

Rys. 5. Ogólna charakterystyka procesu wytlaczania z użyciem dozownika (wytłaczarka podstawowa), prędkość obrotowa ślimaka $N=60 \mathrm{obr} . / \mathrm{min}$

Fig. 5. General characteristcs of the extrusion process (basic extruder), screw speed $N=60 \mathrm{obr} . / \mathrm{min}$

wypełnienia ślimaka FF (ang. fill factor) wyrażony przez stosunek objętości tworzywa w kanale ślimaka do objętości tego kanału. W przypadku procesu wytłaczania z użyciem dozownika SBP jest definiowany jako stosunek objętości tworzywa w stanie stałym do objętości tworzywa w danej objętości kanału ślimaka, która wynika z założonych parametrów symulacji. Jeżeli stopień uplastycznienia jest równy jedności to tworzywo jest w stanie stałym, a jeżeli równy zeru to jest całkowicie uplastycznione. Stopień uplastycznienia $<1$ wskazuje na częściowe uplastycznienie tworzywa. Stopień wypełnienia ślimaka równy jedności oznacza, że kanały ślimak są całkowicie wypełnione tworzywem. Natomiast stopień wypełnienia równy zeru wskazuje na brak wypełnienia ślimaka. W pozostałych przypadkach mamy do czynienia z częściowym wypełnieniem ślimaka.

Podstawowym kryterium zwiększania skali procesu jest również długość układu uplastyczniającego oraz zużycie energii i temperatura tworzywa, niezbędne do wyznaczenia jednostkowego zużycia energii i rozpraszania energii [25].

Wyniki badań procesu zwiększenia skali wytłaczania przedstawiono w tabl. 1 oraz na rys. 6 i 7.

Minimum wartości funkcji celu, czyli najmniejszą rozbieżność między parametrami procesu odniesienia i procesu projektowanego uzyskano przy prędkości obrotowej ślimaka $N=60 \mathrm{obr} . / \mathrm{min}$, temperaturze cylindra $T_{\mathrm{I}}=150^{\circ} \mathrm{C}$, $T_{\text {II }}=190^{\circ} \mathrm{C}, T_{\text {III }}=190^{\circ} \mathrm{C}, T_{\text {IV }}=210^{\circ} \mathrm{C}$, dozowaniu tworzywa $Q_{t w S T}=40 \mathrm{~kg} / \mathrm{h}$. Tym parametrom odpowiadają następujące wartości danych wyjściowych procesu projektowanego, tj. jednostkowe zużycie energii $E_{j S T}=446 \mathrm{~kJ} / \mathrm{kg}$, temperatura na wyjściu z głowicy $T_{t w S T}=209^{\circ} \mathrm{C}$ i względna „długość uplastyczniania" $L_{\text {uplast } S T}=0,700$. Wartości parametrów procesu odniesienia i procesu projektowanego są zbliżone (tabl. 1), dlatego można przyjąć, że badane procesy przebiegają podobnie. Potwierdzają to wyniki 
a)

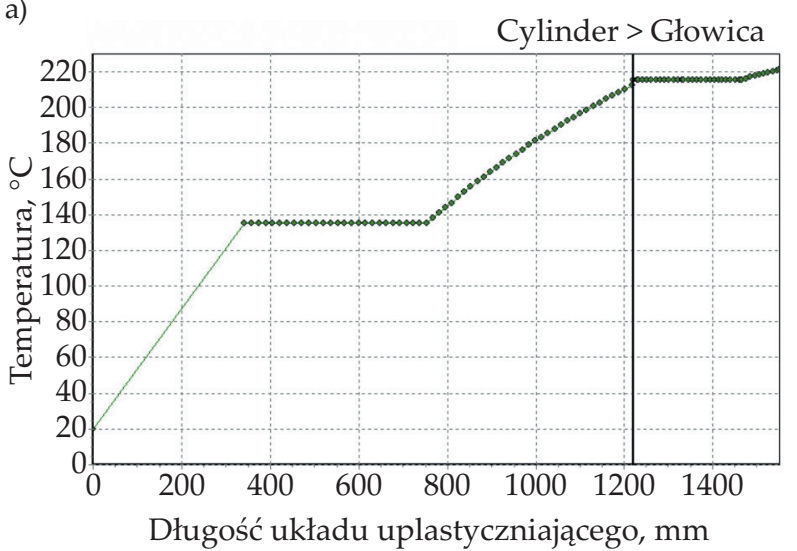

b)

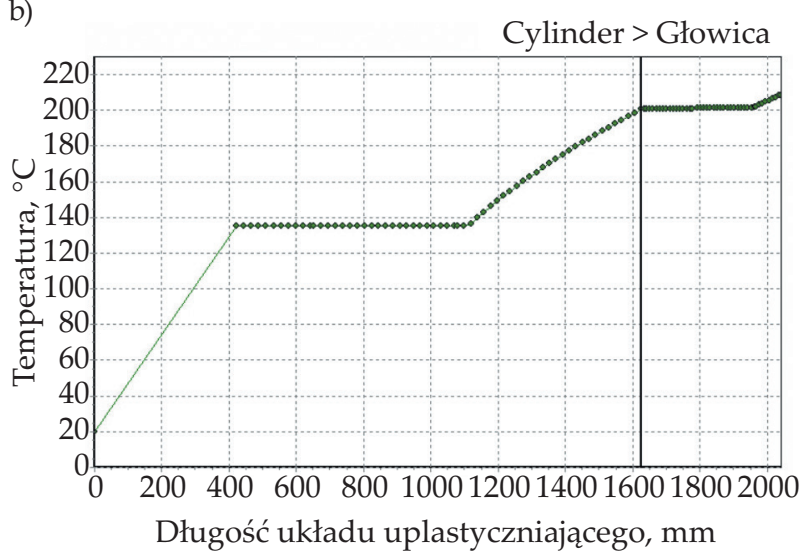

Rys.6. Rozkład temperatury tworzywa: a) wytłaczarka odniesienia $D=45 \mathrm{~mm}$, b) wytłaczarka projektowana $D=60 \mathrm{~mm}$ Fig. 6. Temperature profile: a) reference extruder $D=45 \mathrm{~mm}$, b) target extruder $D=60 \mathrm{~mm}$

a)

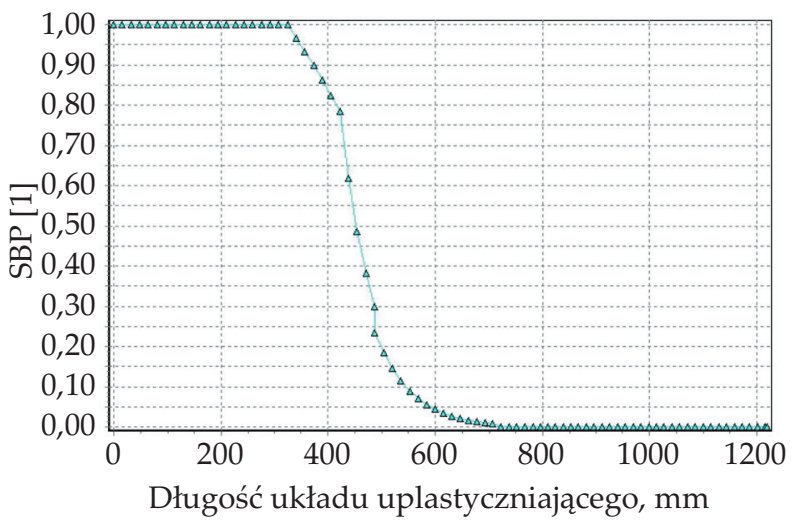

b)

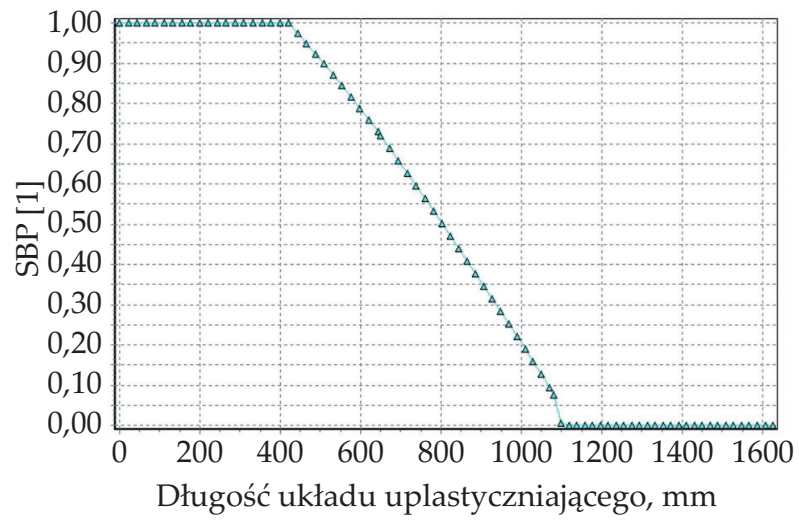

Rys. 7. Stopień uplastyczniania tworzywa SBP (ang. Solid Bed Profile): a) wytłaczarka odniesienia D=45 mm, b) wytłaczarka projektowana $D=60 \mathrm{~mm}$

Fig. 7. Solid bed profile (SBP): a) reference extruder $D=45 \mathrm{~mm}, \mathrm{~b})$ target extruder $D=60 \mathrm{~mm}$

T a b e l a 1. Wyniki badań zwiększania skali procesu wytłaczania jednoślimakowego

$\mathrm{T}$ a b l e 1. Results of scaling up the single screw extrusion process

\begin{tabular}{l|c|c} 
Parametr & $\begin{array}{c}\text { Wytłaczarka } \\
\text { odniesienia } \\
D=45 \mathrm{~mm}\end{array}$ & $\begin{array}{c}\text { Wytłaczarka } \\
\text { projektowana } \\
\text { D=60 mm }\end{array}$ \\
\hline Jednostkowe zużycie energii, kJ/kg & 453,84 & 446,41 \\
$\%$ & 208,62 \\
Temperatura tworzywa na wyjściu z głowicy, ${ }^{\circ} \mathrm{C}$ & 223,31 & 0,700 \\
Względna „długość uplastyczniania” & 0,761 & 6,58 \\
Wydajność wytłaczania, kg/h & 27,32 & 40,11 \\
\hline
\end{tabular}

symulacji rozkładu temperatury i przebiegu uplastyczniania tworzywa w wytłaczarce odniesienia i wytłaczarce projektowanej (rys.6 i 7). W wyniku zwiększenia skali uzyskano znaczący wzrost wydajności procesu wytłaczania (tabl. 1).

Do kodowania stosowanych parametrów, tj. prędkości obrotowej ślimaka, temperatury trzech stref układu uplastyczniającego wytłaczarki oraz szybkości dozowania tworzywa, zastosowano ciągi binarne o długości 7 znaków $\left(2^{7}=128\right.$ wartości), co oznacza $128^{5}=3,44 \cdot 10^{10}$ różnych konfiguracji. Zmiana prędkości obrotowej przy tym ciągu binarnym wynosi $0,5 \mathrm{obr} . / \mathrm{min}$, zmiana temperatury $0,7^{\circ} \mathrm{C}$, a zmiana szybkości dozowania tworzywa $0,05 \mathrm{~kg} / \mathrm{h}$.

\section{PODSUMOWANIE}

Przedstawiono oryginalną metodę zwiększania skali procesu wytłaczania jednoślimakowego z dozowaniem tworzywa przy użyciu dozownika. Procedurę opracowano na podstawie modelu symulacji komputerowej procesu i algorytmów genetycznych. Podstawę metody 
stanowi program do zwiększania skali GASES ST. Obliczenia przeprowadzono wg kryterium minimalnego jednostkowego zużycia energii, maksymalnej wydajności i minimalnej temperatury tworzywa na wyjściu z głowicy. Opracowana metoda jest uniwersalna i może być zastosowana do różnych metod wytłaczania.

\section{LITERATURA}

[1] Covas J.A., Gaspar-Cunha A., Oliveira P.: International Journal of Forming Processes 1998, 1, 323.

[2] Covas J.A., Gaspar-Cunha A., Oliveira P.: Polymer Engineering and Science 1999, 39, 443. https://doi.org/10.1002/pen.11434

[3] Covas J.A., Gaspar-Cunha A.: "The Use of an Optimisation Approach to the Design of Extrusion Screw", Materiały konferencyjne The Polymer Processing Society Sixteenth Annual Meeting (PPS16), Shanghai, Chiny 2000.

[4] Covas J.A., Gaspar-Cunha A.: International Polymer Processing 2001, 16, 229. https://doi.org/10.3139/217.1652

[5] Nastaj A., Wilczyński K.: Polimery 2018, 1, 38. https://doi.org/10.14314/polimery.2018.1.6

[6] Nastaj A., Wilczyński K.: Polimery 2018, 4, 297. https://doi.org/10.14314/polimery.2018.4.7

[7] Covas J.A., Gaspar-Cunha A.: International Polymer Processing 2009, 24, 67.

https://doi.org/10.3139/217.2200

[8] Gaspar-Cunha A., Covas J.A., Vergnes B.: "An Optimisation Methodology for Setting the Operating Conditions in Twin-Screw Extrusion", Materiały konferencyjne The Polymer Processing Society Eighteenth Annual Meeting (PPS-18), Guimaraes, Portugalia 2002.

[9] Gaspar-Cunha A., Poulesquen A., Vergnes B., Covas J.A.: International Polymer Processing 2002, 17, 202. https://doi.org/10.3139/217.1701

[10] Covas J.A., Gaspar-Cunha A., Vergnes B.: Polymer Engineering and Science 2005, 45, 1159. https://doi.org/10.1002/pen.20391

[11] Gaspar-Cunha A., Covas J.A.: International Journal of Natural Computing Research 2014, 4, 17. https://doi.org/10.4018/ijncr.2014010102

[12] Denysiuk R., Recio G., Covas J.A., Gaspar-Cunha A.: Polymer Engineering and Science 2018, 58, 493. https://doi.org/10.1002/pen.24732

[13] Covas J.A., Gaspar-Cunha A.: "A Scaling-up Methodology for Co-rotating Twin-Extruders", Materiały konferencyjne the $27^{\text {th }}$ Annual Meeting of the Polymer Processing Society (PPS-27), Marrakesh, Maroko, 10-14 maja 2011, str. 1.

[14] Berzin F., David C., Vergnes B.: International Polymer Processing 2020, 35, 422. https://doi.org/10.1515/ipp-2020-350504

[15] Nastaj A.: Polimery 2020, 5, 380. https://doi.org/10.14314/polimery.2020.5.6
[16] Nastaj A.: Polimery 2020, 6, 468. https://doi.org/10.14314/polimery.2020.6.6

[17] Nastaj A., Wilczyński K.: Polymers 2020, 12, 149. https://doi.org/10.3390/polym12010149

[18] Wilczyński K., White J.L.: Polimery 2008, 53, 754. https://doi.org/10.14314/polimery.2008.754

[19] Wilczyński K., Nastaj A., Lewandowski A., Wilczyński K.J.: Polimery 2011, 56, 45. https://doi.org/ 10.14314/polimery.2011.045

[20] Wilczyński K., Lewandowski A., Wilczyński K.J.: Polymer Engineering and Science 2012, 52, 1258. https://doi.org/10.1002/pen.23076

[21] Lewandowski A., Wilczyński K.J., Nastaj A., Wilczyński K.: Polymer Engineering and Science 2015, 55, 2838. https://doi.org/10.1002/pen.24175

[22] Wilczyński K., Lewandowski A., Wilczyński K.J.: Polymer Engineering and Science 2012, 52, 1258. https://doi.org/10.1002/pen.23076

[23] Wilczyński K., Nastaj A., Wilczyński K.J.: International Polymer Processing 2013, 28, 34. https://doi.org/10.3139/217.2640

[24] Wilczyński K.J., Nastaj A., Lewandowski A. et al.: Polymer Engineering and Science 2014, 54, 2362. https://doi.org/10.1002/pen.23797

[25] Gale M.: Advances in Polymer Technology 1997, 16, 251. https://doi.org/10.1002/(SICI)1098-2329

[26] Thompson M.R., Donoian G., Christiano J.P.: Polymer Engineering and Science 2000, 40, 2014. https://doi.org/10.1002/pen.11334

[27] Wilczyński K.J., Lewandowski A., Nastaj A. et al.: International Polymer Processing 2016, 31, 82. https://doi.org/10.3139/217.3154

[28] Wilczyński K.J., Lewandowski A., Nastaj A. et al.: Advances in Polymer Technology 2017, 36, 23. https://doi.org/10.1002/adv.21570

[29] Wilczyński K.J., Lewandowski A., Wilczyński K.: Polymer Engineering and Science 2016, 56, 1349. https://doi.org/10.1002/pen.24368

[30] Wilczyński K.J., Nastaj A., Wilczyński K.: Advances in Polymer Technology 2018, 37, 2142. https://doi.org/10.1002/adv.21873

[31] Wilczyński K., Nastaj A., Lewandowski A. et al.: International Polymer Processing 2015, 30, 113. https://doi.org/10.3139/217.3007

[32] Wilczyński K., Buziak K., Wilczyński K.J. et al.: Polymers 2018, 10, 295. https://doi.org/10.3390/polym10030295

[33] Rauwendaal C.: "Polymer Extrusion", Carl Hanser Verlag, Munich 2014.

[34] Hensen F., Knappe W., Potente H.: "Handbuch der Kunststoff-Extrusiontechnik. Grundlagen", Carl Hanser Verlag, Munich 1989.

[35] McKelvey J.M.: "Polymer Processing", John Wiley \& Sons Inc, New York 1962.

[36] Stevens M.J., Covas J.A.: "Extruder Principles and Operation”, Springer, Berlin/Heidelberg 1995. 
[37] Campbell G.A., Spalding M.A.: "Analyzing and Troubleshooting Single-Screw Extruders", Carl Hanser Verlag, Munich 2013.

[38] Chung Ch.I.: "Extrusion of Polymers. Theory and Practice", Carl Hanser Verlag, Munich 2019.

[39] Chen B., Zhu L., Zhang F. et al.: "Process Development and Scale-Up. In Developing Solid Oral Dosage Forms", Elsevier, Amsterdam 2017, str. 821.

[40] Wilczyński K.: "Rheology in Polymer Processing. Modeling and Simulation", Carl Hanser Verlag, Munich 2021.
[41] Wilczynski K., Nastaj A., Lewandowski A. et al.: Polymer-Plastics Technology and Engineering 2012, 51, 626.

https://doi.org/10.1080/03602559.2012.659313

[42] Wilczynski K., Nastaj A., Lewandowski A. et al.: Polymers 2019, 11, 2106.

https://doi.org/10.3390/polym11122106

[43] Nastaj A.: Polimery 2021, 6, 331.

https://doi.org/10.14314/polimery.2021.6.1

[44] Nastaj A., Wilczyński K.: Polymers 2021, 13, 1547. https://doi.org/10.3390/polym13101547

Otrzymano 2 VIII 2021 r. 